\title{
Credit Flows, Fiscal Policy, and the External Deficit of Bosnia and Herzegovina
}

\author{
Daniel Kanda
}





\title{
IMF Working Paper
}

European Department

Credit Flows, Fiscal Policy, and the External Deficit of Bosnia and Herzegovina

Prepared by Daniel Kanda

Authorized for distribution by Dimitri Demekas

December 2006

\begin{abstract}
This Working Paper should not be reported as representing the views of the IMF. The views expressed in this Working Paper are those of the author(s) and do not necessarily represent those of the IMF or IMF policy. Working Papers describe research in progress by the author(s) and are published to elicit comments and to further debate.

This paper develops and estimates a model of the trade balance of Bosnia and Herzegovina. Credit flows and the fiscal stance are found to play a significant role in determining the trade balance. On this basis the paper discusses the trade-offs between monetary and fiscal policy settings needed to achieve a clear downward path for the large current account deficit of Bosnia and Herzegovina.
\end{abstract}

JEL Classification Numbers:C13, C51, E17, E63, F41

Keywords: Fiscal, monetary, credit, trade balance

Author's E-Mail Address: $\underline{\text { dkanda@,imf.org }}$ 


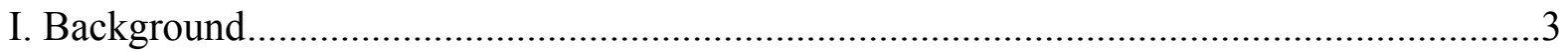

II. A Theoretical Model of the Trade Balance .......................................................................5

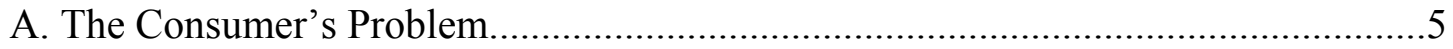

B. The Firm's Problem .......................................................................................

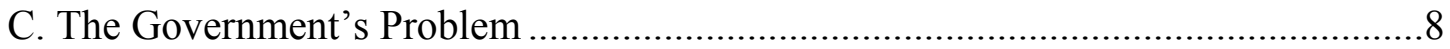

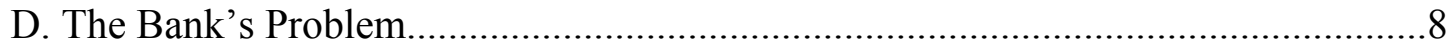

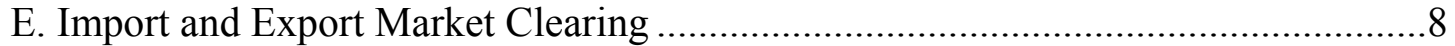

F. The Trade Balance...................................................................................... 8

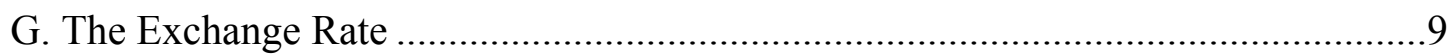

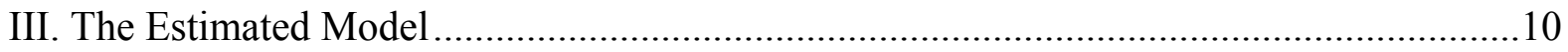

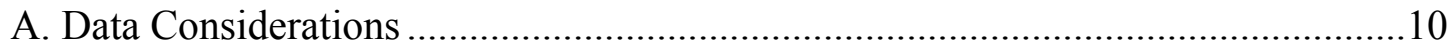

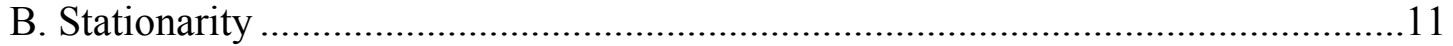

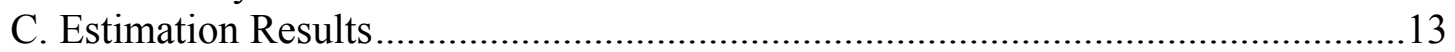

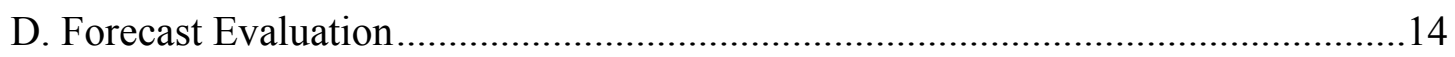

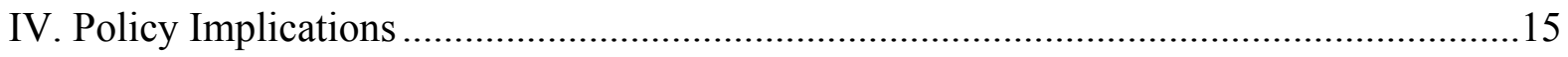

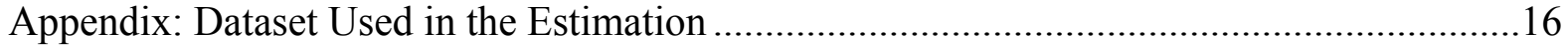

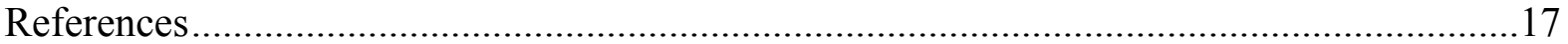




\section{BACKGROUND}

This paper develops a theoretical model of the trade balance and uses it as the basis for estimating a quarterly regression model of Bosnia and Herzegovina's trade balance. The estimated model is then used to shed light on the policy trade-offs between fiscal and credit policy in seeking to target a given reduction in the external deficit.

Bosnia and Herzegovina has a large trade deficit - 50 percent of GDP in 2005- which has been deteriorating in recent years (Table 1). The size of the external imbalance largely reflects negative domestic saving due to widespread corporate lossmaking, but the recent adverse trends appear to be caused by a strong and persistent credit boom since 2002.

Booming credit has resulted from the entry of new foreign-owned banks as well as a surge in bank deposits following the introduction of euro notes and coin at the end of 2001. Several subsidiaries of large European banks have entered the Bosnian banking system, fostering keen competition for market share. Moreover, when the old euro area currencies were phased out, Bosnians exchanged a substantial portion of their holdings of these currencies into deposits with the banking system, in addition to KM currency holdings.

Table 1. Bosnia and Herzegovina: Key Macroeconomic Indicators

\begin{tabular}{|c|c|c|c|c|c|}
\hline & 2001 & 2002 & 2003 & 2004 & 2005 \\
\hline & \multicolumn{5}{|c|}{ Percentage change } \\
\hline Credit to the private sector & 13.7 & 36.2 & 24.8 & 27.5 & 27.5 \\
\hline Exports (in Euro) & 3.4 & -7.9 & 11.5 & 28.7 & 24.0 \\
\hline Imports (in Euro) & 8.3 & 2.5 & 6.0 & 7.6 & 13.6 \\
\hline Retail price index & 3.2 & 0.3 & 0.6 & 0.2 & 2.8 \\
\hline \multirow[t]{2}{*}{ Real GDP } & 3.6 & 5.0 & 4.1 & 5.8 & 5.0 \\
\hline & \multicolumn{5}{|c|}{ In percent of GDP } \\
\hline Trade deficit & 53.3 & 53.8 & 53.2 & 49.5 & 50.2 \\
\hline Current account deficit & 13.3 & 19.1 & 20.9 & 19.3 & 21.3 \\
\hline Credit to the private sector & 22.4 & 28.9 & 34.2 & 40.5 & 48.0 \\
\hline General government balance & -4.5 & -3.3 & -2.0 & -0.4 & 0.9 \\
\hline Domestic saving & -31.4 & -30.2 & -28.6 & -25.7 & -25.4 \\
\hline
\end{tabular}

Sources: Data from the Bosnian authorities; and IMF staff estimates.

The bulk of credit flows have gone to households rather than the corporate sector. With much of the corporate sector in bad shape as a result of soft budget constraints, labor market rigidities, and damage from the war, banks have shied away from corporate lending until recently. Thus, export potential has remained limited - exports were only one-third of imports in 2005. On the other hand, imports have grown strongly in most years, as booming credit has increased demand pressures. 
The deterioration in the external deficit has occurred despite significant fiscal consolidation. Between 2001 and 2005 the overall fiscal balance strengthened by $5 \frac{1}{2}$ percentage points of GDP. However, in this same period, credit to the private sector rose by $253 / 4$ percentage points of GDP, and evidently overwhelmed any negative impact the fiscal consolidation may have had on the external deficit.

And despite booming credit and strong demand pressures, self-sustained economic growth has yet to take root because of the poor state of the corporate sector. Although GDP in 2005 was still substantially below pre-war levels, GDP growth rates have fallen from an average $22^{3 / 4}$ percent during 1996-2000 to an average of only 43/4 percent during 2001-05. ${ }^{1}$ High growth rates in the immediate aftermath of the civil conflict have given way to growth rates that are insufficient to generate the increases in living standards that Bosnians generally desire. As a result, the unemployment rate is estimated to be over 20 percent, and poverty rates are high.

At an estimated 21 percent of GDP in 2005, the current account deficit is well above levels generally associated with sustainability. Thus, bringing it down to a sustainable level while at the same time increasing economic growth and employment represents the key economic challenge facing Bosnia and Herzegovina. Achieving this goal will require deep restructuring of the corporate sector over the medium term to entrench profit-seeking behavior and thus increase domestic savings and exports. However, this will need to be supported by demand restraint, particularly in the short run, to ensure that the current account deficit does not widen further before the corporate reforms take hold.

Demand restraint will have to come from further fiscal tightening, credit restraint, or a combination of the two. This raises the question of just how to calibrate policy. How tight should the fiscal stance be? How much credit growth is too much? What is the trade-off between the fiscal stance and credit growth?

The estimated model indicates that credit to households has a strongly negative impact on the trade balance, well above the impact of credit to enterprises. Fiscal revenue and expenditure both have strong effects on the trade balance as well. And a contraction of 1 percent of GDP in fiscal expenditure has a similar impact on the trade balance as a reduction of 1 percent of GDP in overall credit to the private sector.

However, the currency board arrangement and open capital account imply that most traditional monetary policy instruments are unavailable or ineffective in restraining credit. With an open capital account and a banking system dominated by foreign-owned banks with ample liquidity from their parents, the effectiveness of the rate of required reserves - the only monetary policy instrument available under the currency board - in restraining credit is very limited. Thus, given the substantial difficulties associated with targeting credit growth, the burden of generating demand restraint would have to fall more heavily on fiscal policywhich can be more precisely targeted.

\footnotetext{
${ }^{1}$ The very high growth rates in 1996-2000 reflect the low base following the end of the civil conflict in 1995.
} 


\section{A Theoretical Model of the Trade Balance}

Since the aim is to estimate a (reduced form) empirical model of the trade balance, I will not specify a dynamic mathematical model with explicit functional forms, but rather use a static general equilibrium approach and general functional forms to identify the key explanatory variables of interest and shed light on how they affect the trade balance. Dynamics in the data would then be captured by the inclusion of appropriate lags of the explanatory variables in the regression equation.

The approach used here is an adaptation of the liquidity effects model of Lucas (1990), Fuerst (1992), and Christiano and Eichenbaum (1995), where the representative household separates into different agents during each period but reintegrates at the end of the period. In those articles, this feature eliminates the need to track wealth effects for the different agents and allows the development of a tractable dynamic model incorporating a liquidity effect. In the static setting in this paper, it also provides a simple framework which allows for the introduction of a government agent and a reasonably complete description of the key interactions determining the trade balance. For simplicity I abstract from labor market considerations.

Assume that the Bosnian economy can be represented by a small open economy, with a single representative household which contains four agents - the consumer, the firm, the bank, and government. The household is endowed with fixed amounts of capital $(K)$ and loanable funds $(L)$. In addition, it receives a grant of foreign aid $(A)$. There are two composite tradable commodities which are imperfect substitutes; an exportable good represented by $(E)$, and an importable good represented by $(M)$. The importable good is produced abroad, while the exportable good is produced domestically. Assume all markets are competitive, and that the Bosnian economy is so small relative to the international economy that Bosnian agents take the foreign currency prices of both exportables and importables as given.

This theoretical economy is assumed to exist for only one period. At the beginning of the period, the household splits into the four agents. The loanable funds and foreign aid are placed in the bank to finance its lending activities, while the capital stock is given to the consumer. The firm rents capital from the consumer, and also purchases the importable commodity for use as an input in the production of the exportable commodity. The consumer goes to the market place to purchase both types of commodities for utility-yielding consumption. The government receives tax revenue from the consumer and also makes transfers to the consumer. Then at the end of the period, all the agents come back to form a single household, pool all resources together and pay all outstanding debts.

\section{A. The Consumer's Problem}

The consumer derives utility from the consumption of both types of commodities, and has a utility function given by $U\left(C_{M}, C_{E}\right)$, where $C_{M}$ and $C_{E}$ denote the consumption of the importable commodity and the exportable commodity, respectively. In order to purchase these commodities the consumer needs resources, obtained by borrowing from the bank, by 
receiving a transfer from the government, or from after-tax income from renting the capital stock to the firm. Thus, the consumer faces the following budget constraint:

$$
P_{M} C_{M}+P_{E} C_{E}=\Psi+\Phi^{C}
$$

Where $P_{M}$ and $P_{E}$ represent the prices of the importable commodity and the exportable commodity, respectively, in domestic currency, which the consumer takes as given.

$\Psi$ represents the consumer's disposable income, and is given by

$$
\Psi=r K(1-T)+\Gamma
$$

where $r, T$ and $\Gamma$ represent the rental rate on capital, the tax rate on income received from renting capital, and transfers from the government, respectively.

Finally, $\Phi^{C}$ represents bank credit to the consumer. Bank credit is assumed to be entirely at the discretion of the bank, and so is exogenous to the consumer. We assume that the consumer's desired consumption level is significantly higher than his disposable incomewhich appears to be the case in Bosnia and Herzegovina - such that any amount of credit the bank approves will be used for consumption.

The consumer's problem is to maximize utility, subject to the budget constraint (1). The solution to this problem yields the consumer's demand functions for the two commodities as follows:

$$
\begin{aligned}
& C_{M}=C_{M}\left(P_{E}, P_{M}, \Psi, \Phi^{C}\right) \\
& C_{E}=C_{E}\left(P_{E}, P_{M}, \Psi, \Phi^{C}\right)
\end{aligned}
$$

Under standard assumptions regarding the utility function, and given that there are only two commodities, the consumer's demand for each commodity will be decreasing in own-price, and increasing in the price of the other commodity, disposable income, and bank credit.

\section{B. The Firm's Problem}

The firm produces the exportable commodity using capital and the importable commodity according to the production function $F\left(f_{K}, f_{M}\right)$, where $f_{K}$ and $f_{M}$ represent the quantity of inputs of capital and the importable commodity used in the production process, respectively. The firm is also assumed to be credit constrained, in that it has no liquid assets. Thus, in order to produce it must first borrow from the bank, and then use the borrowed funds to purchase the importable inputs and rent capital. Here also, the bank decides how much to lend to the firm, based on its assessment of the firm's creditworthiness and profitability, and therefore the amount of credit received is exogenous to the firm. Thus, the firm's problem is to choose $f_{K}$ and $f_{M}$ to maximize its profits, given by 
Subject to the constraint

$$
P_{E} F\left(f_{K}, f_{M}\right)-P_{M} f_{M}-r f_{K}
$$

$$
P_{M} f_{M}+r f_{K}=\Phi^{F}
$$

Where $\Phi^{F}$ represents the bank credit to the firm. Solving this problem yields input demand functions given by:

$$
\begin{aligned}
& f_{M}=f_{M}\left(P_{E}, r, P_{M}, \Phi^{F}\right) \\
& f_{K}=f_{K}\left(P_{E}, r, P_{M}, \Phi^{F}\right)
\end{aligned}
$$

Under standard assumptions regarding the production function, and with only two inputs, the firm's input demands are increasing in $P_{E}$, decreasing in own-price, increasing in the price of the other input, and increasing in credit to the firm.

Market clearing in the market for capital requires that the firm's demand for capital should equal the available capital stock. Therefore we have the condition:

$$
K=f_{K}\left(P_{E}, r, P_{M}, \Phi^{F}\right)
$$

Given the capital stock, prices, and credit, the rental rate for capital must adjust to ensure market clearing. Solving for this equilibrium level of $r$ from equation (9) then yields:

$$
r=r\left(P_{E}, P_{M}, \Phi^{F}, K\right)
$$

Substituting (7), (8) and (10) into the production function gives us the maximum value function

$$
F^{\max }\left(P_{E}, P_{M}, \Phi^{F}, K\right)
$$

which gives the total output of the exportable commodity, given prices, capital stock, and bank credit to the firm. $F^{\max }$ (.) is increasing in $P_{E}, \Phi^{F}$, and $K$, and decreasing in $P_{M}$. Since exportables not consumed domestically are exported, the export supply function is given by:

$$
\begin{gathered}
E=F^{\max }\left(P_{E}, P_{M}, \Phi^{F}, K\right)-C_{E}\left(P_{E}, P_{M}, \Psi, \Phi^{C}\right) \\
=E\left(P_{E}, P_{M}, K, \Psi, \Phi^{C}, \Phi^{F}\right)
\end{gathered}
$$

Inspection of $F^{\max }($.$) and C_{E}($.$) indicates that export supply is increasing in P_{E}, \Phi^{F}$ and $K$, and decreasing in $\Phi^{C}, P_{M}$ and $\Psi$. 


\section{The Government's Problem}

A very simple structure is assumed, where the government obtains funds by taxing the consumer and borrowing from the bank and then spends these funds as a transfer to the consumer. Issues related to the government's objectives are not considered, for simplicity. Thus we have

$$
\Gamma=r K T+\Phi^{G}
$$

where $\Phi^{G}$ represents bank credit to government, and is also the fiscal balance.

\section{The Bank's Problem}

The bank receives loanable funds and the foreign aid grant from the household, which it lends to the other agents following an exogenous credit assessment process. The bank cannot lend more than the available loanable funds, and any leftover funds following its credit operations are kept as a reserve $(R)$. I abstract from the determination of interest rates charged on bank credit. Thus we have

$$
L+A-R=\Phi^{C}+\Phi^{F}+\Phi^{G}
$$

\section{E. Import and Export Market Clearing}

Assume that Bosnia and Herzegovina is sufficiently small relative to international markets, and that there are sufficiently close substitutes for its exports, such that it is a price taker in both exportables and importables markets. Thus, given these exogenous prices the quantities of exports and imports are then determined by the optimizing decisions of the consumer and firm with regard to consumer and input demands and exportables output.

\section{F. The Trade Balance}

Now combining equations (2) and (13) yields:

$$
\Psi=r K+\Phi^{G}
$$

Substituting equations (10) and (15) into equations (3) and (12), substituting equation (10) into equation (7), and noting that total demand for imports (represented by $\Pi_{M}$ ) is given by the sum of consumer and firm demand for the importable commodity, we obtain:

$$
\begin{gathered}
\Pi_{M}=C_{M}\left(P_{E}, P_{M}, K, \Phi^{G}, \Phi^{C}\right)+f_{M}\left(P_{E}, P_{M}, K, \Phi^{F}\right) \\
=\Pi_{M}\left(P_{E}, P_{M}, K, \Phi^{G}, \Phi^{C}, \Phi^{F}\right)
\end{gathered}
$$

And the trade balance $(B)$, denominated in foreign currency, is given by 


$$
B=P_{E}^{*} E\left(P_{E}, P_{M}, K, \Phi^{G}, \Phi^{C}, \Phi^{F}\right)-P_{M}^{*} \Pi_{M}\left(P_{E}, P_{M}, K, \Phi^{G}, \Phi^{C}, \Phi^{F}\right)
$$

Here $P_{E}^{*}$ and $P_{M}^{*}$ represent the prices in foreign currency of the exportable and importable commodities, which are related to the respective domestic currency prices as follows:

$$
\begin{aligned}
P_{M} & =e P_{M}^{*} \\
P_{E} & =e P_{E}^{*}
\end{aligned}
$$

where $e$ represents the domestic currency price of a unit of foreign currency. Substituting equations (18) and (19) into (17) then yields the trade balance function

$$
B\left(P_{E}^{*}, P_{M}^{*}, e, K, \Phi^{G}, \Phi^{C}, \Phi^{F}\right)
$$

Considering equations (17) and (20), note that with the exception of credit to households and credit to government - which unambiguously have an inverse relation with the trade balance - all other explanatory variables have an ambiguous impact on the trade balance. For example, an increase in the price of exportables increases export supply, but also increases import demand; an increase in the price of importables reduces export supply but has an ambiguous effect on the overall value of imports (last expression in equation (17)); a change in the exchange rate changes the domestic currency prices of exportables and importables, which then has ambiguous effects on the trade balance; credit to firms increases the supply of exportables but also increases the demand for imported inputs; and an increase in the capital stock increases both export supply and import demand. Thus, the net impact of changes in the explanatory variables on the trade balance will differ across countries, and will depend on the relative sizes of the various components of the trade balance and the responsiveness of each component to changes in the explanatory variables.

\section{G. The Exchange Rate}

The demand for foreign currency in the model is driven completely by imports, while the supply of foreign currency is driven by exports and foreign aid. Equilibrium in the foreign exchange market then requires the equalization of demand and supply of foreign exchange, given by:

$$
A+P_{E}^{*} E\left(P_{E}^{*}, P_{M}^{*}, e, K, \Phi^{G}, \Phi^{C}, \Phi^{F}\right)=P_{M}^{*} \Pi_{M}\left(P_{E}^{*}, P_{M}^{*}, e, K, \Phi^{G}, \Phi^{C}, \Phi^{F}\right)
$$

Solving equation (21) then yields the equilibrium exchange rate as a function of foreign aid, credit flows, capital stock, and export and import prices. In principle, we could substitute for the exchange rate in equation (19) to yield a trade balance function in which the exchange rate is no longer an explanatory variable, but where foreign aid inflows are. However, since data on the exchange rates are generally much more accurate than those on aid inflows I stick with equation (19) as the model of the trade balance to be estimated. 


\section{The Estimated ModeL}

Assume that equation (20) is well approximated by a linear function. On this basis a linear regression model was specified. Initially, many lags of the explanatory variables were included to capture any dynamics in the data. A general-to-specific approach was then employed, where lags found to be not statistically significant were eliminated. The exchange rate variable (which was taken to be the nominal effective exchange rate) was also dropped from the model because it was not significant, and its deletion did not adversely affect the forecasting ability of the model. However, the ratio of export to import prices (proxied as described below) was found to be significant, with a stable coefficient, and this is therefore how the price variables are introduced into the regression. Finally, seasonal dummies were also included. This approach yielded the following regression model:

$$
B_{t}=a_{0}+a_{1} s_{1, t}+a_{2} s_{2, t}+a_{3} s_{3, t}+a_{4} \Phi_{t-1}^{F}+a_{5} \Phi_{t-1}^{C}+a_{6} F R_{t-2}+a_{7} F E_{t}+a_{8} P E M_{t}+a_{9} T R_{t-1}+a_{10} \varepsilon_{t}
$$

Where $s_{1}, s_{2}$, and $s_{3}$, are seasonal dummies for the first three quarters, and $F R, F E, \varepsilon$, $P E M$, and TR represent fiscal revenue, fiscal expenditure, the error term, the ratio of export prices to import prices, and trend real GDP (see below), respectively.

Interestingly, note that the policy variables - fiscal expenditure, credit flows, and fiscal revenue affect the trade balance with different lags.

\section{A. Data Considerations}

Unfortunately, the lack of data implied need for some improvisations in order to generate the required quarterly data. Proxy variables and interpolated data were used in several cases as a result, as described below. This therefore is a potential source of bias that must be borne in mind when interpreting the results. The Appendix presents the data used in the estimation.

- There are no data on the capital stock. Moreover, the expenditure breakdown of GDP is also unavailable, so it is not possible to calculate a proxy for the capital stock using data on investment expenditure. Thus, trend real GDP is taken to be the proxy variable, based on the assumption that trend GDP is correlated with the productive capacity of the economy, and therefore with capital. Moreover, as the statistical authorities do not publish estimates of real GDP, IMF staff estimates of annual real GDP, were interpolated using the industrial production index to arrive at estimates of quarterly real GDP. The trend was then extracted using the HP filter.

- There are also no price indices available for Bosnia's exports or imports. Thus, the export price index for Europe is taken as a proxy for the Bosnian import price index, and the import price index for Europe as a proxy for the Bosnian export price index.

- However, good quality data on bank credit to households and enterprises are readily available from the monetary survey, and credit flows are calculated as the change in end-period stocks. To calculate credit flow to enterprises this paper adds data from 
the Bank for International Settlements (BIS) on credit by international banks to the Bosnian non-bank private sector to the monetary survey data on domestic bank credit to enterprises.

- From equation (13), credit to government is equivalent to the fiscal deficit, and so this paper focuses on obtaining estimates of the general government revenue and expenditure. Data on general government are only available annually, but monthly fiscal data (which exclude external grants and expenditure on foreign financed projects) are available for the Entity central governments. Thus, to construct estimates of quarterly general government revenue and expenditure this paper interpolated the annual revenue (excluding grants) and expenditure (excluding foreign financed projects) data for the general government using the Entity-level data. In addition, given that off-budget expenditure on foreign-financed projects has been substantial, estimates of quarterly expenditure on foreign-financed projects are then added to those obtained for on-budget expenditure. The quarterly estimates for foreign financed projects were interpolated from annual data, assuming that spending on these projects was evenly distributed throughout the year.

\section{B. Stationarity}

Many empirical studies have found that key macroeconomic variables such as GDP, exchange rates, and interest rates are often non stationary. As is well known, in such cases the estimation techniques and interpretation of results change markedly. Thus we first need to determine the stationarity of the variables in our model. This is done using unit root tests developed by Ng and Perron (2001), which have much improved size and power properties compared to earlier tests such as the Augmented Dickey Fuller and Phillips-Perron tests. Ng and Perron develop four test statistics, all with the same limiting distribution, and Table 2 presents results for all the four tests for unit roots, generated using Eviews software.

The unit root tests reject non-stationarity in all cases (Table 2). Thus, in the estimation levels for the variables are used. 
Table 2. Ng Perron Unit Root Tests of the Dependent and Explanatory Variables

\begin{tabular}{|c|c|c|c|c|c|}
\hline & \multirow{2}{*}{\multicolumn{2}{|c|}{ Test Statistics 1/ }} & \multicolumn{3}{|c|}{ Critical Values } \\
\hline & & & 10 percent level & 5 percent level & 1 percent level \\
\hline \multicolumn{6}{|c|}{ Trade balance } \\
\hline Mza & -38.61 & $* * *$ & -14.20 & -17.30 & -23.80 \\
\hline $\mathrm{MZt}$ & -4.25 & $* * *$ & -2.62 & -2.91 & -3.42 \\
\hline MSB & 0.11 & $* * *$ & 0.19 & 0.17 & 0.14 \\
\hline MPT & 3.12 & $* * *$ & 6.67 & 5.48 & 4.03 \\
\hline \multicolumn{6}{|c|}{ Trend Real GDP } \\
\hline Mza & -32.48 & $* * *$ & -14.20 & -17.30 & -23.80 \\
\hline $\mathrm{MZt}$ & -3.97 & $* * *$ & -2.62 & -2.91 & -3.42 \\
\hline MSB & 0.12 & $* * *$ & 0.19 & 0.17 & 0.14 \\
\hline MPT & 3.13 & $* * *$ & 6.67 & 5.48 & 4.03 \\
\hline \multicolumn{6}{|c|}{ Export price/Import price } \\
\hline Mza & -298.57 & $* * *$ & -5.70 & -8.10 & -13.80 \\
\hline MZt & -12.22 & $* * *$ & -1.62 & -1.98 & -2.58 \\
\hline MSB & 0.04 & $* * *$ & 0.28 & 0.23 & 0.17 \\
\hline MPT & 0.08 & $* * *$ & 4.45 & 3.17 & 1.78 \\
\hline \multicolumn{6}{|c|}{ Flow of credit to enterprises } \\
\hline Mza & -15.37 & $* * *$ & -5.70 & -8.10 & -13.80 \\
\hline $\mathrm{MZt}$ & -2.75 & $* * *$ & -1.62 & -1.98 & -2.58 \\
\hline MSB & 0.18 & $* *$ & 0.28 & 0.23 & 0.17 \\
\hline MPT & 1.68 & $* * *$ & 4.45 & 3.17 & 1.78 \\
\hline \multicolumn{6}{|c|}{ Flow of credit to households } \\
\hline Mza & -125.33 & $* * *$ & -14.20 & -17.30 & -23.80 \\
\hline $\mathrm{MZt}$ & -7.91 & $* * *$ & -2.62 & -2.91 & -3.42 \\
\hline MSB & 0.06 & $* * *$ & 0.19 & 0.17 & 0.14 \\
\hline MPT & 0.73 & $* * *$ & 6.67 & 5.48 & 4.03 \\
\hline \multicolumn{6}{|c|}{ Fiscal revenue (excl. grants) } \\
\hline Mza & -237.53 & $* * *$ & -14.20 & -17.30 & -23.80 \\
\hline $\mathrm{MZt}$ & -10.90 & $* * *$ & -2.62 & -2.91 & -3.42 \\
\hline MSB & 0.05 & $* * *$ & 0.19 & 0.17 & 0.14 \\
\hline MPT & 0.38 & $* * *$ & 6.67 & 5.48 & 4.03 \\
\hline \multicolumn{6}{|c|}{ Fiscal expenditure } \\
\hline Mza & -25.65 & $* * *$ & -14.20 & -17.30 & -23.80 \\
\hline $\mathrm{MZt}$ & -3.56 & $* * *$ & -2.62 & -2.91 & -3.42 \\
\hline MSB & 0.14 & $* * *$ & 0.19 & 0.17 & 0.14 \\
\hline MPT & 3.66 & $* * *$ & 6.67 & 5.48 & 4.03 \\
\hline
\end{tabular}

Source: Author's calculations.

$1 /{ }^{* *}, * *$, and $*$ represent rejection of the unit root hypothesis at the 1 percent, 5 percent, and 10 percent levels, respectively. 


\section{Estimation Results}

Table 3 presents the results from the estimation of equation (22) on quarterly data from the first quarter of 1998 to the second quarter of 2004 . $^{2}$ Estimation was carried out using GMM, with instruments given by the following:

$s_{1}, s_{2}, s_{3}, \Phi_{t-1}^{F}, \Phi_{t-1}^{C}, F R_{t-2}, F E_{t-1}, F E_{t-2}, F E_{t-3}, P E M, O P, O P_{t-1}, T R_{t-1}$, and the constant term, where $O P$ is an oil price index. This allows for possible endogeneity in fiscal expenditure, which enters the regression equation concurrently with the trade balance. The weighting matrix was set in Eviews to ensure that the estimates are robust to heteroskedasticity and serial correlation of unknown form.

Table 3. Estimation Results for Trade Balance Model (Dependent variable, trade balance)

\begin{tabular}{|c|c|c|c|}
\hline & \multicolumn{3}{|c|}{ GMM Estimates } \\
\hline & Coefficient & t-statistic & P-value \\
\hline Constant & -1616.68 & -6.25 & 0.00 \\
\hline Seasonal dummy for Q1 & 29.37 & 0.90 & 0.39 \\
\hline Seasonal dummy for Q2 & -60.90 & -3.46 & 0.00 \\
\hline Seasonal dummy for Q3 & 10.24 & 0.37 & 0.71 \\
\hline First lag of credit flow to enterprises & -0.21 & -2.81 & 0.01 \\
\hline First lag of credit flow to households & -1.08 & -3.51 & 0.00 \\
\hline Second lag of fiscal revenue & 0.39 & 1.88 & 0.08 \\
\hline Fiscal expenditure & -0.45 & -2.17 & 0.05 \\
\hline Export price/Import price & 17.41 & 6.15 & 0.00 \\
\hline First lag of trend real GDP & -0.45 & -1.40 & 0.19 \\
\hline \multicolumn{4}{|l|}{ Memorandum items } \\
\hline R-square & 0.86 & & \\
\hline Test of overidentifying restrictions (Chi-square test, 4df) & 1.68 & & 0.79 \\
\hline Number of observations & 23 & & \\
\hline
\end{tabular}

Source: Author's calculations.

The model appears to provide a good fit to the data. The test of overidentifying restrictions does not find any evidence of misspecification, with a p-value of 0.79 . R-squared is quite high at 0.86 , and most coefficients are estimated with good precision with the exception of trend GDP and some of the seasonal dummies. The coefficients for the explanatory variables all have the expected signs.

\footnotetext{
${ }^{2}$ Data from 2004 Q3 to 2005 Q3 was used for forecast evaluation.
} 


\section{Forecast Evaluation}

Forecast performance also appears to be good. To investigate this, the model was used to generate forecasts of the trade balance for the period Q3 2004 to Q3 2005. ${ }^{3}$ The Theil inequality coefficient (which ranges between 0 and 1, with 0 being a perfect forecast) is only 0.03 , indicating strong forecasting ability, and the root mean squared error of the forecast is about Euro 55 million. The absolute forecast error is on average about 5 percent of the trade balance.

Table 4. Forecast Evaluation of Trade Balance Model (Forecast period: Q3 2004 - Q3 2005)

Root mean squared error

Mean absolute error

Mean absolute percent error

Theil inequality coefficient

Source: Author's calculations.
54.68

44.19

5.18

0.03

Figure 1. Trade balance, Q1 1998 - Q3 2005

Euro million

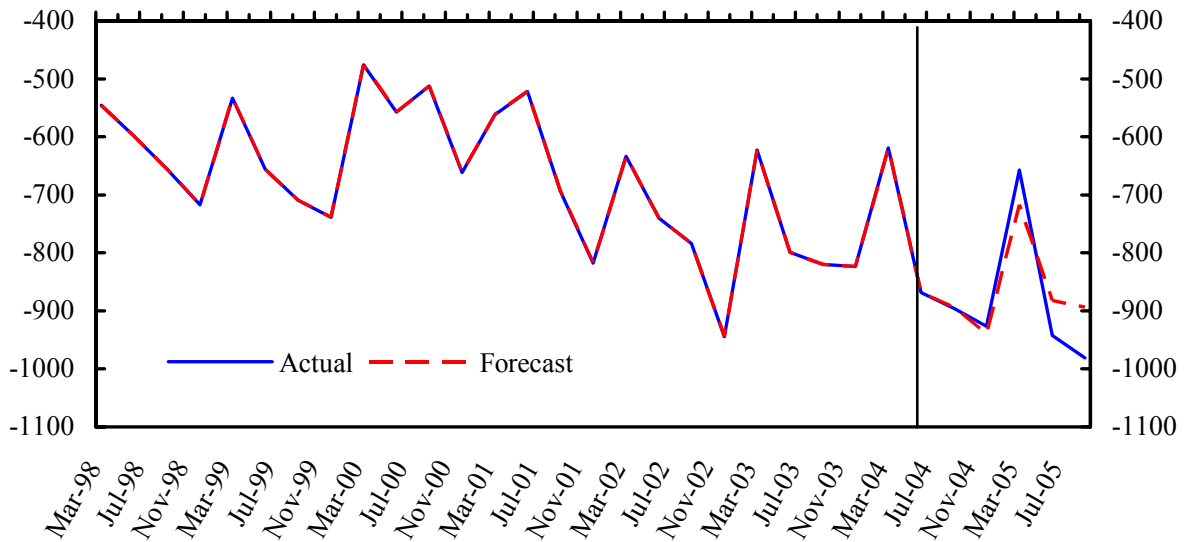

Source: Author's calculations.

This impression of strong forecasting performance is also borne out in Figure 1, which plots the actual and forecasted trade balances. As we can see the actual and forecasted trade balances remain quite close over most of the 5-quarter forecast horizon.

\footnotetext{
${ }^{3}$ A forecast for 2005Q4 is not included because of a large one-off surge in imports in December 2005 ahead of the introduction of VAT in January 2006.
} 


\section{Policy Implications}

The estimated model raises a number of policy issues. First, the impact of a given flow of total credit to the private sector on the trade balance depends strongly on the composition of that credit. The flow of credit to enterprises has a markedly smaller negative impact on the trade balance than that of credit to households. Thus, to the extent that credit flows are led by credit to households, the adverse impact on the external deficit will be larger. This result implies that (if it can be devised) a policy measure targeted primarily at restraining credit to households would be more effective in achieving a desired correction in the external deficit.

The estimated model also indicates that the policy variable with the most immediate impact on the trade balance is fiscal expenditure, followed by credit flows and then fiscal revenue. This suggests that when an immediate correction to the trade balance is needed, the preferred policy option should be fiscal expenditure restraint.

Regarding the relative power of fiscal or credit policy to reduce the trade balance, empirical projections were made using the model, where plausible quarterly paths of the regressors were generated for 2006, and the impact on the trade balance assessed. Given the already heavy burden of taxation, the assessment of fiscal policy focused on a fiscal tightening generated solely through expenditure restraint, while, for credit tightening, the impact of changes in the overall flow of credit to the private sector was considered, keeping the breakdown between credit to households and enterprises the same as observed in 2005. These experiments indicate that a fiscal tightening through a 1 percent of GDP reduction in expenditure over a one-year horizon generates a 0.45 percent of GDP reduction in the trade deficit, whereas a reduction in the flow of credit of 1 percent of GDP over the same horizon generates a 0.44 percent of GDP reduction in the trade deficit. Thus, fiscal expenditure and credit tightening appear to be roughly equally effective in achieving reductions in the trade deficit over a one-year horizon.

However, the currency board and open capital account in Bosnia and Herzegovina imply that it is very difficult to target a particular credit growth rate. Generally, to restrain credit one could either tighten the required reserves regime or tighten prudential regulations. But with the domestic banking system dominated by subsidiaries of foreign banks with access to ample liquidity from their parents, these instruments are typically ineffective. This leaves fiscal policy as the only instrument that can be precisely calibrated to affect the trade balance.

Thus, in practice most of the efforts to restrain demand over the near term should focus on fiscal policy. Over the long term, however, deep structural reforms would be needed to bring the trade deficit down to sustainable levels. 


\section{Appendix}

Dataset Used in the Estimation

\begin{tabular}{|c|c|c|c|c|c|c|c|c|}
\hline & $\begin{array}{r}\mathrm{TB} \\
\text { (millions of euros) }\end{array}$ & $\begin{array}{r}\text { PEM } \\
\text { (Percent) }\end{array}$ & $\begin{array}{r}\mathrm{TR} \\
\text { (millions of euros) }\end{array}$ & $\begin{array}{c}\Phi^{C} \\
\text { (millions of euros) }\end{array}$ & $\begin{array}{c}\Phi^{F} \\
\text { (millions of euros) }\end{array}$ & $\begin{array}{r}\text { FR } \\
\text { (millions of euros) }\end{array}$ & $\begin{array}{r}\mathrm{FE} \\
\text { (millions of euros) }\end{array}$ & $\begin{array}{r}\text { OP } \\
(\text { Euro, } 2000=100)\end{array}$ \\
\hline Mar-98 & -545.6 & 98.9 & $1,039.7$ & 7.1 & 71.2 & 370.8 & 582.1 & 42.9 \\
\hline Jun-98 & -599.0 & 96.1 & $1,059.3$ & 6.3 & -20.1 & 416.6 & 581.7 & 39.7 \\
\hline Sep-98 & -656.0 & 92.4 & $1,078.8$ & 12.3 & 15.3 & 442.0 & 653.1 & 38.2 \\
\hline Dec-98 & -717.7 & 88.4 & $1,098.2$ & 39.0 & 58.7 & 494.4 & 678.4 & 32.8 \\
\hline Mar-99 & -533.2 & 94.7 & $1,117.5$ & 4.1 & -57.6 & 399.3 & 682.9 & 33.8 \\
\hline Sep-99 & -709.4 & 94.3 & $1,155.2$ & -10.7 & 3.0 & 540.7 & 785.4 & 63.5 \\
\hline Dec-99 & -738.8 & 92.5 & $1,173.7$ & 14.6 & -4.6 & 630.2 & 839.7 & 74.7 \\
\hline Mar-00 & -475.7 & 102.0 & $1,191.8$ & 10.1 & 28.0 & 490.8 & 802.9 & 87.9 \\
\hline Jun-00 & -557.8 & 101.4 & $1,209.6$ & 22.2 & 36.8 & 568.3 & 830.2 & 93.4 \\
\hline Sep-00 & -512.6 & 99.5 & $1,227.2$ & 14.3 & 18.7 & 540.4 & 821.8 & 107.6 \\
\hline Dec-00 & -661.5 & 96.8 & $1,244.5$ & 12.8 & 66.9 & 675.8 & 873.1 & 111.2 \\
\hline Mar-01 & -562.2 & 103.2 & $1,261.6$ & 7.3 & -47.4 & 465.9 & 734.2 & 92.0 \\
\hline Jun-01 & -521.7 & 103.1 & $1,278.7$ & 41.7 & 122.8 & 555.3 & 820.6 & 99.7 \\
\hline Dec-01 & -817.5 & 94.0 & $1,312.7$ & 35.3 & 61.3 & 716.0 & 895.8 & 70.3 \\
\hline Mar-02 & -633.8 & 99.2 & $1,329.8$ & 54.8 & 60.0 & 542.3 & 701.8 & 77.8 \\
\hline Jun-02 & -740.5 & 99.9 & $1,347.2$ & 128.4 & -10.9 & 616.1 & 793.1 & 89.2 \\
\hline Sep-02 & -783.9 & 99.4 & $1,364.7$ & 115.9 & 284.2 & 685.1 & 806.7 & 89.2 \\
\hline Dec-02 & -944.8 & 94.3 & $1,382.5$ & 88.4 & 32.7 & 703.0 & 840.2 & 87.4 \\
\hline Mar-03 & -623.1 & 101.2 & $1,400.4$ & 69.3 & -18.3 & 669.9 & 828.4 & 95.1 \\
\hline Jun-03 & -799.0 & 100.6 & $1,418.5$ & 97.2 & 11.1 & 743.7 & 919.8 & 76.0 \\
\hline Sep-03 & -820.0 & 98.7 & $1,436.9$ & 66.8 & 84.3 & 812.7 & 933.3 & 82.3 \\
\hline Dec-03 & -823.7 & 93.2 & $1,455.4$ & 35.9 & 61.3 & 830.6 & 966.9 & 80.4 \\
\hline Mar-04 & -619.2 & 99.2 & $1,474.1$ & 53.4 & 128.0 & 717.5 & 825.5 & 83.7 \\
\hline Jun-04 & -868.4 & 97.0 & $1,492.9$ & 126.3 & 81.4 & 886.6 & $1,011.5$ & 96.4 \\
\hline Sep-04 & -896.1 & 96.1 & $1,511.9$ & 89.8 & 84.7 & 842.7 & 909.8 & 108.1 \\
\hline Dec-04 & -926.9 & 91.9 & $1,531.0$ & 68.5 & 92.0 & 896.5 & $1,037.2$ & 107.4 \\
\hline Mar-05 & -657.3 & 99.6 & $1,550.1$ & 63.9 & 80.2 & 793.1 & 898.0 & 114.3 \\
\hline Jun-05 & -942.2 & 98.6 & $1,569.3$ & 124.9 & 69.2 & 980.7 & $1,070.2$ & 131.3 \\
\hline Sep-05 & -980.8 & 97.3 & $1,588.5$ & 110.1 & 96.6 & 962.7 & 950.8 & 160.2 \\
\hline
\end{tabular}




\section{References}

Bayoumi, T., 1999, "Estimating Trade Equations from Aggregate Bilateral Data,"IMF Working Paper No. WP/99/74 (Washington: International Monetary Fund).

Brussiere, M., M. Fratzscher, and G.J. Muller, 2004, "Current Account Dynamics in OECD and EU Acceding Countries-An Intertemporal Approach," ECB working paper, No. 311 (Frankfurt: European Central Bank).

Christiano, L.J., and M. Eichenbaum, 1995, "Liquidity Effects, Monetary Policy, and the Business Cycle," Journal of Money, Credit, and Banking, Vol. 27, 1113-36.

Chrystal, K.A., and P. Mizen, 2005, “A Dynamic Model of Money, Credit, and Consumption: A Joint Model for the UK Household Sector," Journal of Money, Credit, and Banking, Vol. 37, 119-43.

Fuerst, T.S., 1992, "Liquidity, Loanable Funds, and Real Activity," Journal of Monetary Economics, Vol. 29, 3-24.

Goldstein, M., and M. Khan, 1985, "Income and Price Effects in Foreign Trade," in Handbook of International Economics, ed. by R.W. Jones and P.B. Keenen, Vol II, (Amsterdam: Elsevier).

Hansen, B.E., and K.D. West, 2002, “Generalized Method of Moments and Macroeconomics,” Journal of Business and Economic Statistics, Vol. 20, 460-69.

Jones, J.B., 2003, “The Dynamic Effects of Firm-Level Borrowing Constraints,” Journal of Money, Credit, and Banking, Vol. 35, 743-62.

Kishan, R.P., and T.P. Opiela, 2000, "Bank Size, Bank Capital, and the Bank Lending Channel," Journal of Money, Credit, and Banking, Vol. 32, 121-41.

Li, V.E., 2000, "Household Credit and the Monetary Transmission Mechanism," Journal of Money, Credit, and Banking, Vol. 32, 335-56.

Letendre, M., 2004, "Semi-Parametric Predictions of the Intertemporal Approach to the Current Account," Journal of International Economics, Vol. 64, 363-86.

Lucas, R.E., 1990, “Liquidity and Interest Rates," Journal of Economic Theory, Vol. 50, 237-64.

Mas-Colell, A., M.D. Whinston, and J.R. Green, 1995, Microeconomic Theory, (New York: Oxford University Press).

Ng, S., and P. Perron, 2001, "Lag Length Selection and the Construction of Unit Root Tests with Good Size and Power," Econometrica, Vol. 69, 1519-554. 
Peek, J.P., E.S. Rosengren, and G.M.B. Tootell, 2003, "Identifying the Macroeconomic Effect of Loan Supply Shocks," Journal of Money, Credit, and Banking, Vol. 35, 931-46.

Rudebusch, G.D., 2005, “Assessing the Lucas Critique in Monetary Policy Models,” Journal of Money, Credit, and Banking, Vol. 37, 245-72.

Stock, J.H., and J.H. Wright, 2000, “GMM with Weak Identification,” Econometrica, Vol. $68,1055-096$.

Stock, J.H., J.H. Wright, and M. Yogo, 2002, "A Survey of Weak Instruments and Weak Identification in Generalized Method of Moments," Journal of Business and Economic Statistics, Vol. 20, 518-29.

Stucka, T., 2004, "The Effects of Exchange Rate Change on the Trade Balance in Croatia," IMF Working Paper, No. WP/04/65 (Washington: International Monetary Fund). 